\title{
Science comics as tools for science education and communication: a brief, exploratory study
}

\section{Tatalovic}

\begin{abstract}
Comics are a popular art form especially among children and as such provide a potential medium for science education and communication. In an attempt to present science comics in a museum exhibit I found many science themed comics and graphic books. Here I attempt to provide an overview of already available comics that communicate science, the genre of 'science comics'. I also provide a quick literature review for evidence that comics can indeed be efficiently used for promoting scientific literacy via education and communication. I address the issue of lack of studies about science comics and their readers and suggest some possible reasons for this as well as some questions that could be addressed in future studies on the effect these comics may have on science communication.
\end{abstract}

\section{Objective}

As part of a preparation for an international exhibit of science comics in the new science and technology museum in Rijeka, Croatia, I searched for comics books that aim to communicate science. The main objectives were to identify if there are any science comics and to do an exploratory overview of these comics and to provide a brief review of literature on potential uses of these comics in science education and communication.

\section{Context}

Comics (sequential art) have been generally underrated as a medium and an art form, and in the AngloSaxon world they are frequently thought of as nothing more than a cheap pastime. They are "thrice damned" says Simon Locke (2005; p. 29):

\begin{abstract}
"damned as culture, being popular not 'high'; damned as a medium, being neither art nor literature but some perverse hybrid, at best suitable only for children (and retarded adults), at worst positively harmful . . . and they are damned as a genre, being the most outlandish fantasy involving absurd characters acting in the most bizarre fashion - the very antithesis, one might think, of plausibility." [1]
\end{abstract}

However, for many people comics are much more than this. In Understanding Comics (1994) and Reinventing Comics (2000) Scott McCloud argues for comics' ability to communicate various messages in an artistic way [2,3]. His books, together with Will Eisner's Comics and Sequential Art (1985) and Graphic Storytelling and Visual Narrative (1996) are often used as a good starting point for thinking about the specificities of the comics medium and for considering comics in their own right, separate from other media [4,5].

One can argue against all three damnations of comics identified by Locke. First, if comics are a part of popular culture, this could be a strength as it allows them to reach many people of various backgrounds. However, not all comics are popular culture, as the work of certain artists demonstrates (e.g. Satrapi's Persepolis and Spiegelman's Maus). One could argue that such comics are both art and literature, and in some ways more than either one of these on its own. Moreover, there are a variety of genres of comics, not all of which include "outlandish fantasy" and "absurd characters". Whatever view one takes of 
comics though, they have played an important role in the history of media in the last couple of centuries, and are still widely available both in shops and online, with graphic novels becoming popular and earning mainstream acceptance as a literary art form (e.g. see [6]).

Comics' status as a lowly medium for the masses and the fact that they appeal to children have perhaps been the main reasons why they were largely and somewhat unfairly ignored by academia, something most critical appraisals of comics are quick to state. Here I will focus mainly on the subset of studies on comics: those that have looked at connections between science and comics. I will briefly review such studies and their conclusions. I will then give an overview of the genre of comic books that aim to communicate science: the science comics. I will complete the paper by outlining the gaps in current knowledge about science comics and about any role that they might play in science communication.

\section{Terminology: defining 'comics'}

I agree with McCloud (1994) that single-frame cartoons relate to comics as photographs do to film [2]. Comics, as sequential art are different to cartoons and to general cartoon illustrations found in many educational books (e.g. Horrible Science series or Icon Books' Introduction to... series). The fact that there is a sequence of related images (frames) that make up a story distinguish comics from simple illustrations which may invoke comic imagery but are at the end of the day a part of different media, be it a primarily text-based book, image-based poster, etc.

There may be some similarities between book illustrations and comics: for example, when comparing educational books about dinosaurs from 1978 with those from 1998 Buckingham and Scanlon (2003; p. 133 ) found that in recent books "text has effectively become a commentary on the images, whereas in the older books the bulk of the text was independent of the image" [7]. This closer association between text and image in more recent books is reminiscent of comics where text and images work together to create an emerging medium that is neither just the text nor just the images but an emergent whole, composed of both. But as interesting as this trend of closer association between image and text in illustrated educational books is, it does not necessarily warrant studying books with cartoon illustrations and comic books together, as though they were the same medium.

So, while cartoons and comics both use images associated with text, comics is a medium in its own right, defined roughly as 'sequential art'. Failure to distinguish between sequential art and non-sequential cartoon illustrations is perhaps one of the reasons why there is so little literature dedicated specifically to examining science in comics (Alice Bell, personal communication). Comic book imagery abounds in various books, games and TV programs and unless one specifically defines comics as separate from cartoons and illustrations in other media it becomes very difficult to focus on the specificity of comics as a medium and to say anything meaningful about them. It is as if one were to discuss science films by looking at both photographs and films, instead of just focusing on the medium of moving images; one could not possibly study film in as much depth if one also had to include photographs, because much of what is particular about film would have to be overlooked. Indeed, there are researchers who are studying non-animated science cartoons in their own right, as a medium separate from comics (Sai Pathmanathan, personal communication).

Comic strips, although more similar to comic books than cartoons in that they can also narrate a story through a short sequence of frames are still quite different from comic books; they could legitimately be studied on their own account and either be included in or excluded from a study on science comics. Schmitt (1992) likens comic strips to book illustrations rather than comic books because in strips words and images are more independent of each other than they are in comic books and are thereby read differently from comic books [8]. I mentioned them here briefly because they are related and could legitimately be studied together with comic books; however, I focus this paper specifically on science comic books, which are longer than comic strips and allow a more complex narrative to develop. In the words of Douglas Wolk (2007; p. 18), I take comics to be "sustained narrative, which means comic books and graphic novels, much more than newspaper comic strips or one-off cartoon illustrations" [9].

There is no definition of comics that satisfies everyone and that includes everything that people consider as 'comics'. In the compilation of essays on comics The Language of Comics (2001; p. xvi), editors Gibbons and Varnum say that some of the contributors in their book see "...comics as a narrative form consisting of pictures arranged in sequence" while for others "...it is juxtaposition of words and pictures, not sequence, that is essential to the comics form" [10]. They conclude that "comic strips, comic books, 
graphic novels, single-panel cartoons, wordless comics, animated cartoons and various other kinds of visual texts bear family resemblances to one another" although no definition can at the same time be specific enough and encompass all those forms [10]. I have argued here that they can conceivably be four levels or categories of related art: single-frame cartoons, short comic strips, comic books and graphic novels, in order of ascending length and level of narrative complexity. In this paper I will focus mainly on comic books, a term I use interchangeably with comics.

\section{Studies on science in comics}

\subsection{Fiction comics and science}

Although some studies have emphasised that comics and animated cartoons, two of the traditionally most popular media enjoyed by young people, offer a distorted and stereotypical view of science and scientists [11], many common fiction comics actually contain references to accurate scientific ideas and facts [12]. For example, a variety of valid chemistry principles, equations and processes are referred to in comics as diverse as Donald Duck and Marvel Classic Comics [12]. Perhaps not surprisingly, then, fiction comics can be effectively used in enhancing learning about biochemistry - using excerpts from manga comics helps students memorize concepts [13] - and have been suggested as a possible interesting teaching aid to teach laboratory safety and ethics - by critiquing poor lab safety often depicted in comics students could be introduced to potentially dull issues in a visually entertaining way [14]. Popular, fiction comics have been used to convey environmental and laboratory safety messages (e.g. the Archie Comics: Archie and Friends Battle Toxic Household Wastes and Let's Have a Blast), albeit with an unknown success [15].

Comics are sometimes able to convey nuanced issues in scientific ethics: echoing Locke's 2005 findings that comics can carry sophisticated ideas about science and its social context Weinstein (2006, p. 972) finds that in Truth, the comic book about black soldiers who were used as guinea pigs in WW2, "there are no easy places to escape to in this story, no sense that science can make it all right. In this way Truth presents a more complicated vision of science and ethics than either GPZ [professional magazine] or the official texts" [17].

Comics have also been used for promoting health and the psychological means of coping with childhood diseases such as cancer and diabetes; examples include Captain Chemo comics and Omega Boy vs Dr. Diabetes [17]. Some of these have actually been conceived and drawn by the child patients themselves, perhaps showing their need and inclination for such content to be delivered in a comic book medium and might represent a true engagement of non-scientists with science. Others are produced by publishing companies with an aim to provide medical information in a format appropriate for children, such as Medikidz, a series of comic books about various paediatric conditions.

Fiction comics, especially the super-hero style comics often contain characters with powers that defy known scientific explanations, and yet their authors try to make them scientifically justified so that the characters make sense within the reality of the comic book narrative [1]. "The stories are based in science, and in magic, legend and mythology," Locke says, "They're all thrown into the mix, but the universe that's constructed is scientifically coherent and there's an attempt to give scientific legitimacy to super powers." (cited in [18]). As such, super-hero comics are "one cultural arena where the public meaning of science is actively worked out" says Locke (2005; p. 25) [1]. Comic book super-heroes have inspired a number of science museum exhibitions such as the 'Marvel Superhero Science Exhibition' at the California Science Center [19]; fiction comics have also been used in museums to illustrate concepts and generally enliven exhibitions (e.g. the use of a Martin Mystery comic book page at the Natural History Museum in Milan to illustrate a paleontologist's equipment, or Dan Dare comic excerpts at the Science Museum in London) (personal observation).

Super-hero comics have also inspired teachers to use examples from the comics to teach science, The Science of Superheroes (2002) and The Physics of Superheroes (2005) being two excellent books about the science behind the superpowers and how to use those in teaching students about science [20,21]. What transpires from these books is that fiction comics often get the science 'facts' wrong but can still be used as interesting examples of why something is wrong and what science tells us about such phenomena (e.g. see [22]). Taking a step further in using comics to communicate science, we arrive to non-fiction comics whose purpose is to get the science right. But in such comics the importance of the scientific 
message becomes paramount, opening possibility that the quality and entertainment value of the comic book suffer as a consequence.

\subsection{Educational comics and science}

Comic books produced specifically for science communication constitute a special genre, one which is often ignored by researchers. I feel that more research should focus on these non-fiction science comics. I use the term non-fiction with caveat here, because even comics which explain real-life scientific phenomena use many fictional elements and techniques in order to do so. Indeed, the use of fiction can enhance the enjoyment of reading as well as more effectively deliver scientific content to children who readily discern fictional elements from non-fictional ones [23]. This is why I prefer to talk about 'science comics': comics which have as one of their main aims to communicate science or to educate the reader about some non-fictional, scientific concept or theme, even if this means using fictional techniques and narratives to convey the non-fictional information. For this reason, in the rest of the paper I focus primarily on these science comics, and not the fiction comics that may contain some reference to science but have no intention, agenda or responsibility to educate their readers in science.

Educational non-fiction comics dealt with scientific topics from 1941 in the mainstream Classics Illustrated comics and the World Around Us series, and these have now been suggested as good materials to teach the history of science as many of them focused on topics from the history of science [24]. Single frame cartoons were used to discuss science publicly as early as the $19^{\text {th }}$ century [25]. Wright (2002) described how cartoons and comics have been used to communicate medical science over the past two centuries and Hansen (2004) mapped in great detail highly commercially successful comics that dealt in celebratory manner with real scientists and medical doctors in the 1940s [26,27].

This special genre of educational science-themed comics may help to promote and explain science to students and the general public. There is now some evidence that educational comics and related singleframe cartoons can be useful for teaching science. This evidence suggests they can make children think about science, and help in teaching them curriculum science [23,28-31], and can be useful in making the general public think about science [32]. Children enjoy reading comics and both the visual appeal of a graphic representation and the tendency towards intriguing narrative (which can be humorous while educational) make comics an excellent vehicle for conveying scientific concepts in an interesting way [30]. In most of these studies comics are said to make learning about science in the classroom more diverse and therefore more interesting, but these studies rarely control for the novelty factor of such lessons - children might be happy to use comics and learn more just because it is something different than their normal classroom routine: the beneficial results might not have anything specific to do with the comic book medium itself. Some of the studies are conducted on very small samples sizes, and hardly any address the effects of science comics on adults' understanding of science. These and similar considerations warrant further studies before use of comics should become fully embraced in science education and communication [33].

Nevertheless, from my exploratory research of science comics, it appears that scientists and educators are becoming more aware of the appeal that comics hold for young people and are starting to use them more as a vehicle to communicate scientific ideas. Although educational comics about science are no new invention, their production appears to be blossoming in the current climate of focus on the public understanding of science and public engagement with science and technology. As a result, in the last decade or so a variety of educational science comics and cartoons have been produced, by a variety of publishers, partially reviewed here.

\section{Review of science comics}

\subsection{Educational science cartoons and comic strips}

A popular form of science communication in India, 'Scientoons' are the brainchild of Indian scientist and science communicator Pradeep Srivastava [34]. These cartoons contain a caricature accompanied by a 

(see Image 1).

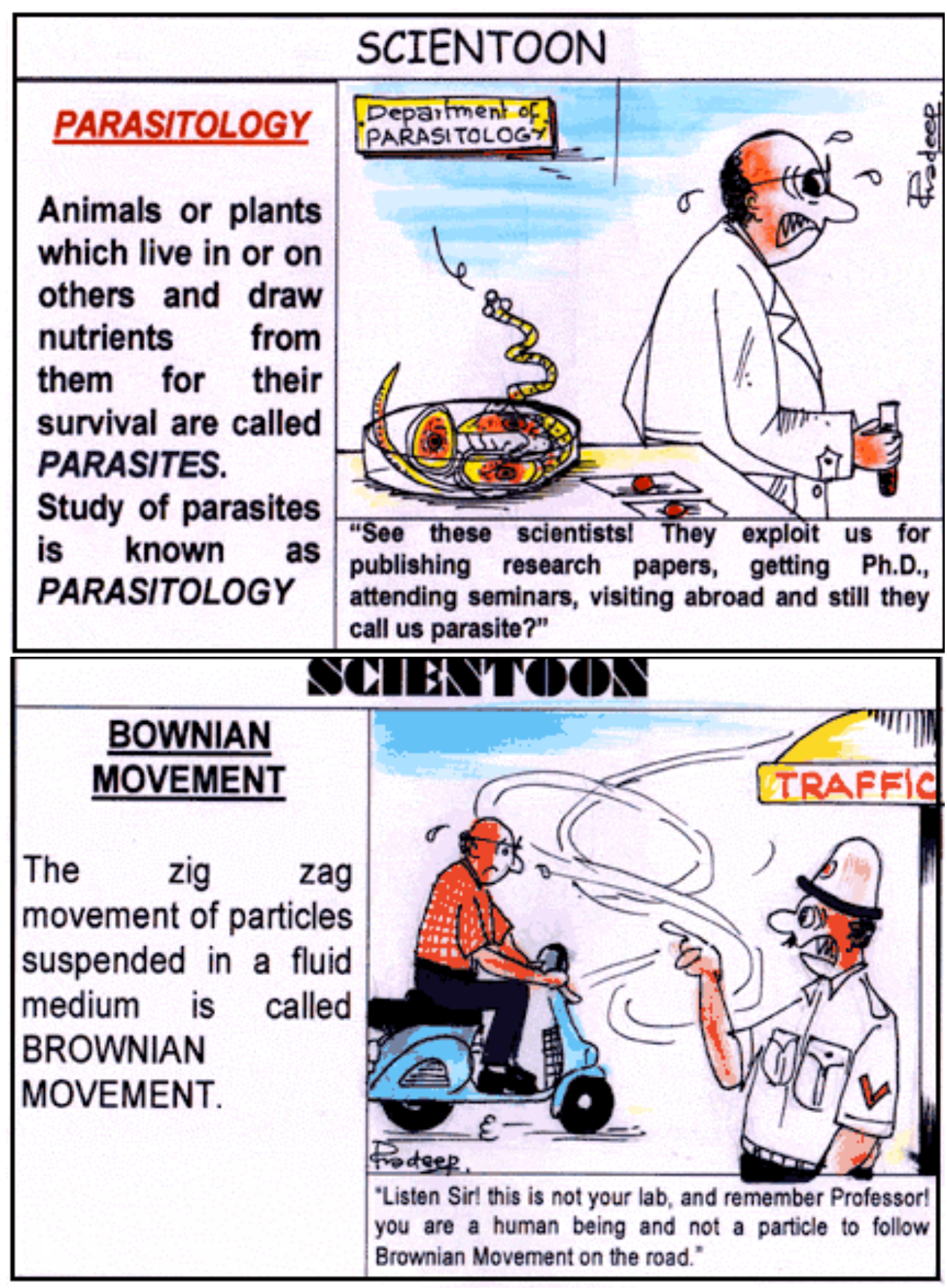

Image 1. Two examples of Scientoons. (C) Pradeep Srivastava, www.scientoon.com Reprinted with permission.

Another example are single-frame "Concept Cartoons" which have been used to improve physics education and public interest in science [32,35]. These depict a single problem such as: "would the snowman [featured in the cartoon] melt faster, slower or at the same rate if we put a coat around it?" 
Offering no immediate solution, they make people think about the problem and discuss it with others $([32,35]$; see Image 2).

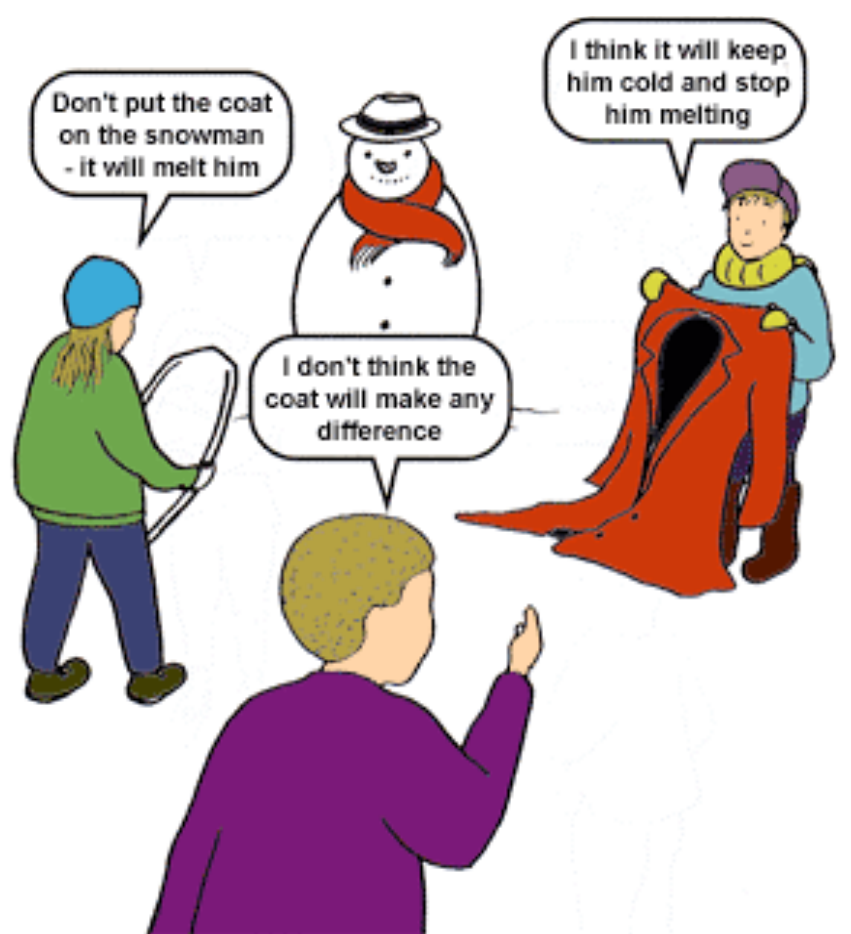

Image 2. An example of a Concept Cartoon. Title: Concept Cartoons in Science Education. Publisher: Millgate House Publishing Ltd. Author: Brenda Keogh and Stuart Naylor. Date: 1999. Website: http://www.millgatehouse.co.uk.

Like cartoons, comic strips may also have a role in communicating science. Several websites provide short online comic strips that deal with or are inspired by scientific topics. For example LabRatz is a three-frame comic strip inspired by day-to-day life in a scientific laboratory and office space, while $P h D$ Comics draw their inspiration from lives of graduate students doing their scientific research. Newton and Copernicus follows the adventures of two lab rats and has been successfully used in science education to raise scientific literacy of students [31]. Some online comic strips only address science occasionally, but can still make interesting observations and stimulate discussion such as the Saturday Morning Breakfast Cereal Comics (see Image 4).

This brief summary illustrates that science can be communicated via single-frame cartoons and short comic strips.
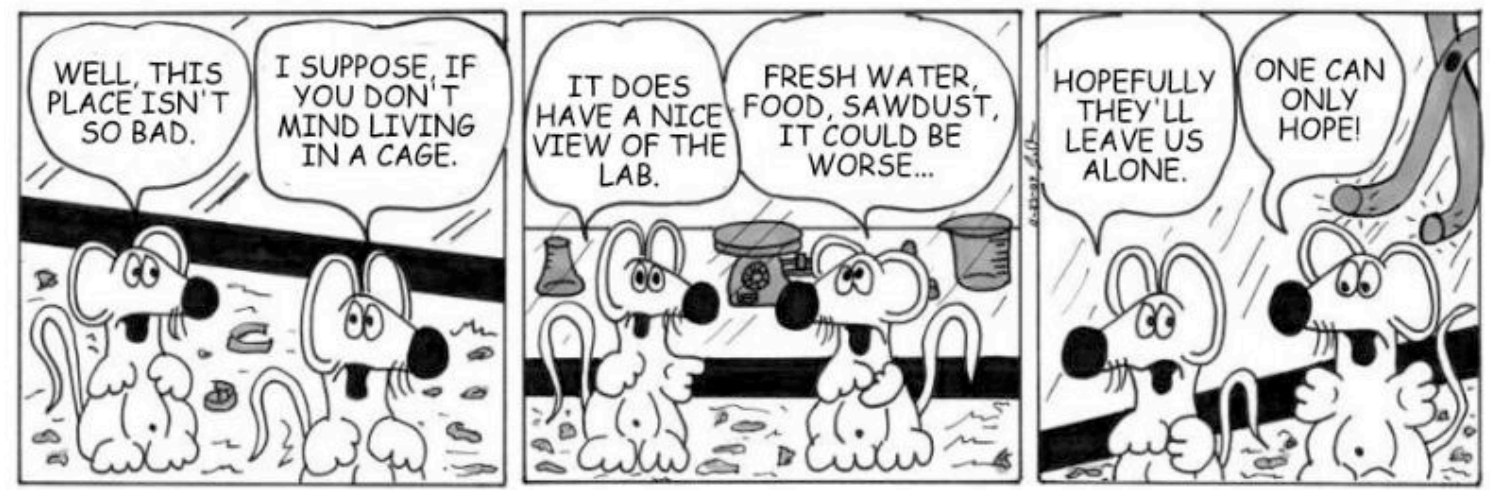

Image 3. Newton and Copernicus comic strip example. C J.C. Olson, http://www.newtonandcopernicus.com/ Reprinted with permission. 


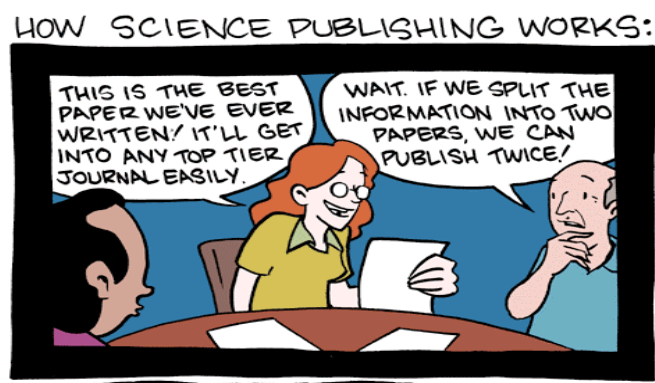

HOW SCIENCE REPORTING WORKS:
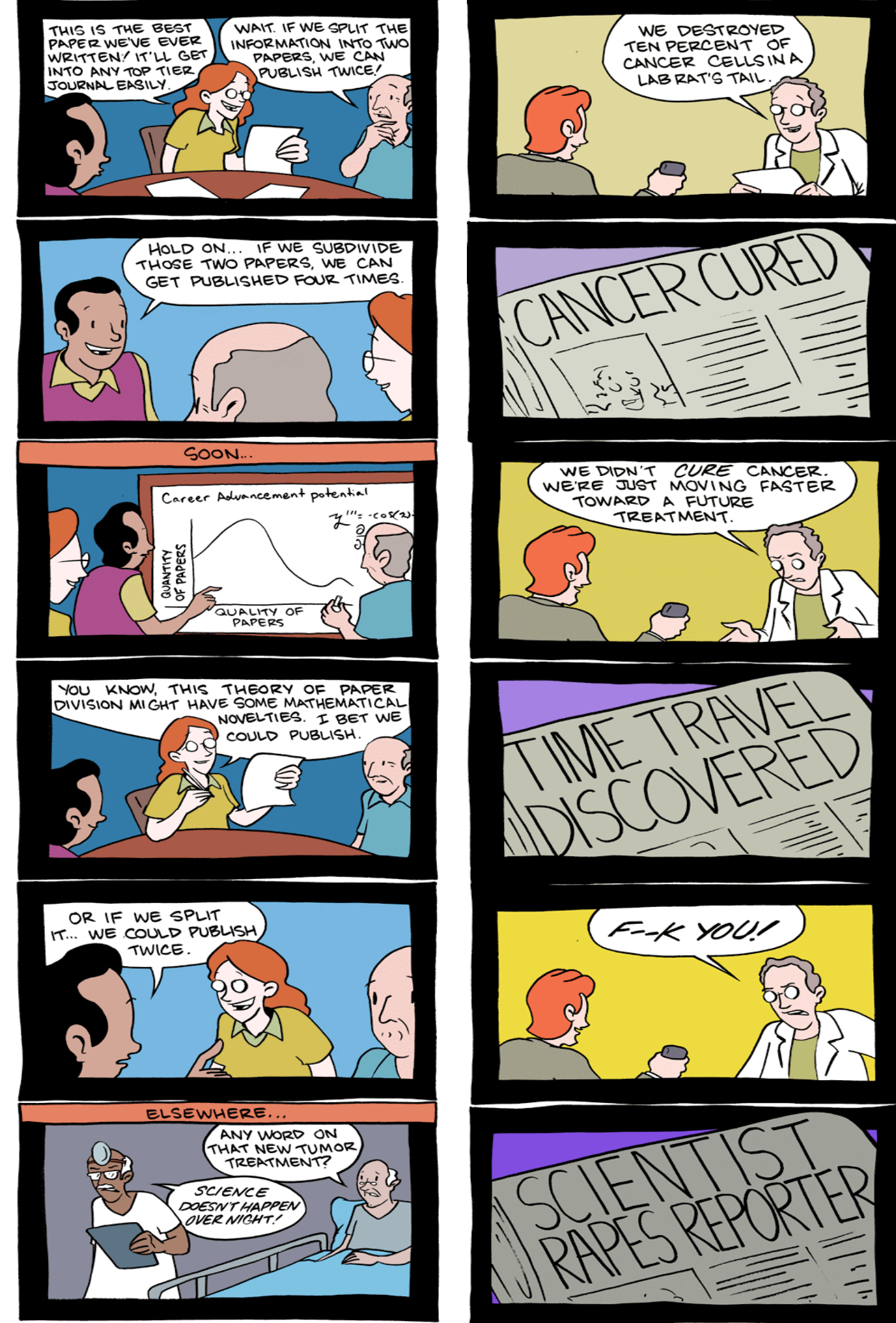

Image 4. Two Saturday Morning Breakfast Comic Strips. http://www.smbc-comics.com/ Reprinted with permission. 


\subsection{Science comics and graphic novels}

The Solar-Terrestrial Environment Laboratory of Nagaya University in Japan has produced a series of 9 colourful manga-style comics so far, each 16 pages long and dealing with a different topic: global warming, solar radiation, geomagnetism, cosmic rays, polar regions, the aurora, the upper atmosphere, ozone holes and the sun-climate relationships (in Japanese and English, but freely available for translation into other languages as well).

Jean-Pierre Petit produced a series of black-and-white "scientific comic books" called The Adventures of Archibald Higgins: they treat various scientific topics including black holes, the theory of relativity and the big bang theory [36]. Petit's series has been translated into more than 30 languages so far, and is freely available online.

Capstone Press in the USA has recently (2007-09) published a series of superhero-style Max Axiom comics, comprising 19 books so far. They cover a variety of topics from electromagnetism to natural selection and are aimed at students aged 8-14. The series' eponymous super-hero is Max, a scientist who explains science through his adventures in which he can shrink down to the size of an ant, ride on a sound wave, and presumably makes science appear 'cool'.

In India there is a comic book magazine, The Young Scientists, aimed at 5-13 year-olds, and in the UK, the chemistry comic book series The Chemedian is designed to teach national curriculum chemistry to pupils aged 7-10. The makers of The Chemedian (The Chemedian has now been re-branded to Selenia) were awarded $£ 72,779$ by the government to develop a series of ten comics [38]. They say that their comic brings laughter to the classroom and encourages students to engage with science [30].

Also, in the UK, the Biotechnology and Biological Sciences Research Council funded the project of turning real life research and scientists (from PhD students to professors at the Rothamstead Research Institute in Hertfordshire) into comic stories and characters. Science Stories book came out in two issues (in 2002, and 2006) and it is composed of short comics featuring such titles as Slugging it Out, Down in the Dirt, How to Confuse a Moth, Sulphur Power and Killer Caterpillar: each book outlines some of the research that has been going on at Rothamstead Research Institute. These comics, available freely online, are written by Emma Naper, a science research student from Southampton University, and drawn by professional illustrator Phil Elliot; as such they demonstrate a fruitful collaboration between arts and sciences to produce a piece of science communication in a comic book medium.

Interferon Force is action-packed comic book series depicting the battle between the immune system's interferon molecules and flu viruses [Influenza Attacks! (2007)] and other factors in autoimmune diseases [Cytokine Storm! (2008)]. The second issue, Cytokine Storm! was serialized and published in eight parts in the Nature Immunology journal. Readers are encouraged to engage with the comic online by voting for the next villain to appear in the series and by an interactive gallery of characters that blends their anthropomorphic features with their known roles in immunology.

Space Weather (2000), an adventure comic about solar radiation, satellites, space climate, planetary orbits and fusion, is produced by the Big Time Attic studio and published by the US National Oceanic and Atmospheric Administration (NOAA). This was followed by two more comic books featuring the same main characters: Space Junk (2005) and the Journey Along a Field Line (2000) (a story about earth's magnetic field, published by the US Geological Survey). EU's Eco Agents Special Unit (2007) has a series of online comics about ecological themes, titles include Ocean Wind and Sustain and Gain.

Generally, each issue of these comic book series deals with a single main subject, has an engaging narrative which explains the science involved, and features some sort of a glossary or introduction explaining the scientific terms.

I found other, one-off science comics. These include Water Heroes (2007), a manga-style comic book about conservation of water resources produced by the Environment Canada and several comics by Jay Hossler such as Conundrum of a Corona Virus, a 2-page, detective-story style comic about SARS, originally published in Emerging Diseases: New and Old. Others are Adventures in Synthetic Biology [38], a story about the new interdisciplinary field of synthetic biology, originally published in Nature (see Image 5), and Cindi in Space [39], a super-hero style comic about the ionosphere and satellites, produced by University of Texas at Dallas, and inspired by already mentioned Space Weather [40]. 


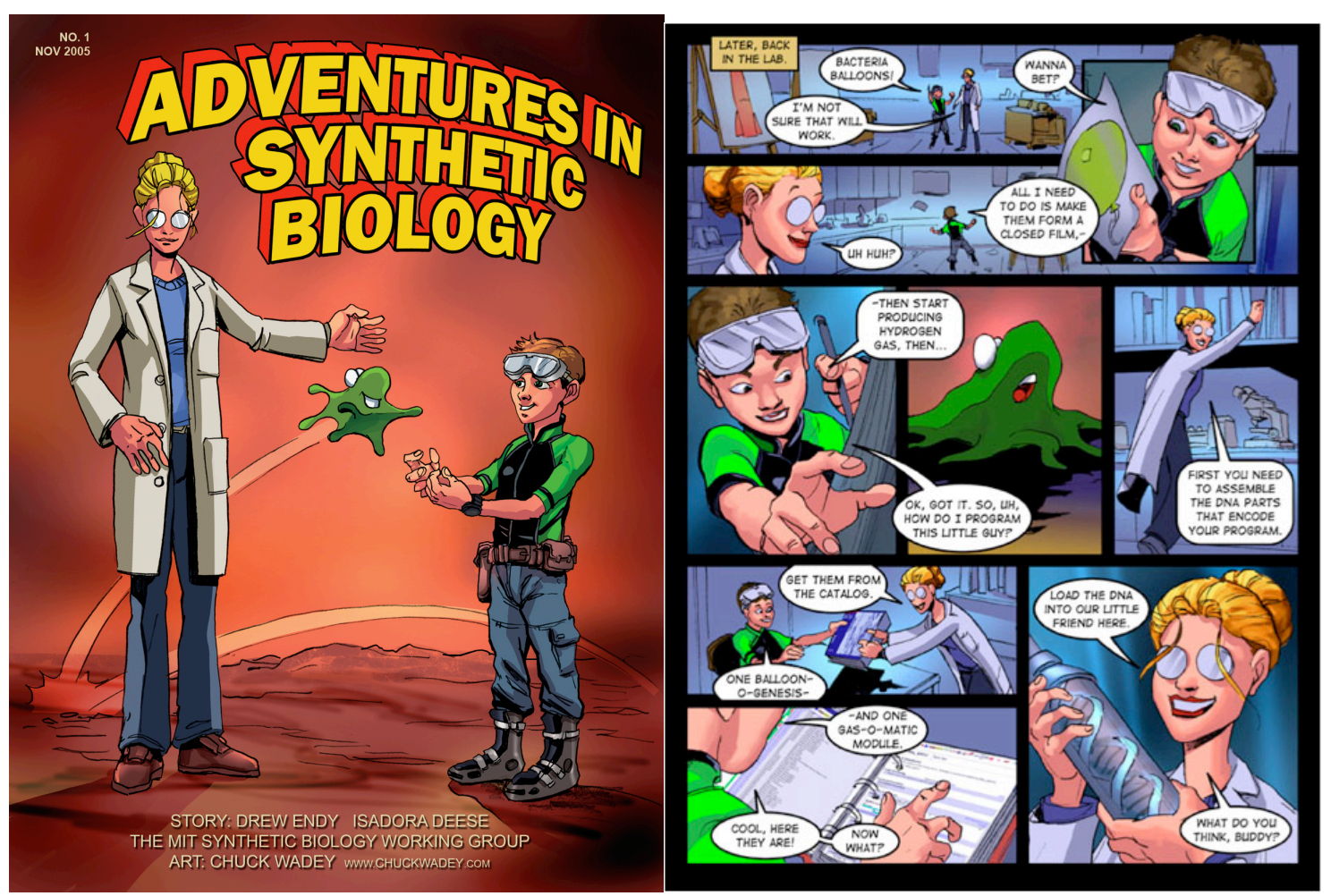

Image 5. A cover and an excerpt from the Adventures in Synthetic Biology comic book. Reprinted with permission.

Although most science comics I came across were in English, and this paper is focused on the English language comics, examples in other languages also exist, these include I Ja želim Biti Kao Prelog [I Also Want To Be Like Prelog] [41] about chemistry Nobel Laureate Vladimir Prelog, published in Croatian, and Al Otro Lado del Telescopio: Los Descubrimientos de Galileo [On the Other Side of the Telescope: Galileo's Discoveries] [42] about Galileo Galilei in Spanish.

Apart from science comic books there are several longer graphic novels available. These deal with various topics in biology and physics (see table 1). Some of these are aimed at children, such as Clan Apis, whilst others are for older audiences. Most of these are black and white, unlike the colourful shorter comic books: this reflects a larger trend in which comic books are generally in colour while most notable graphic novels are black and white (e.g. Joe Sacco's Safe Area Goražde and Palestine, and Delisle's Pyongyang: A Journey in North Korea). But who reads these graphic novels and for what purpose? Are they read in order to learn more about science or primarily for fun? Do people who are not already interested in science ever read these novels? These are all questions awaiting future study. 


\begin{tabular}{|c|c|c|}
\hline Name of the comic (year published) & Topic & Author \\
\hline Clan Apis (2000) & $\begin{array}{l}\text { Entomology: } \\
\text { behaviour of bees }\end{array}$ & Jay Hossler \\
\hline $\begin{array}{l}\text { The Sandwalk Adventures: An Adventure in Evolution Told } \\
\text { in Five Chapters (2003) }\end{array}$ & Natural selection & Jay Hossler \\
\hline Optical Allusions (2007) & Eyesight & Jay Hossler \\
\hline Suspended in Language (2004) & $\begin{array}{l}\text { Story of Niels Bohr's } \\
\text { life and scientific } \\
\text { discoveries }\end{array}$ & Jim Ottaviani \\
\hline Fallout (2001) & $\begin{array}{l}\text { Science and politics of } \\
\text { the first atomic bombs }\end{array}$ & Jim Ottaviani \\
\hline Dignifying Science (2003) & $\begin{array}{ll}\begin{array}{l}\text { Famous women in } \\
\text { science }\end{array} & \\
\end{array}$ & Jim Ottaviani \\
\hline Two-Fisted Science (2001) & $\begin{array}{l}\text { Various stories from } \\
\text { the histroy of science }\end{array}$ & Jim Ottaviani \\
\hline Levitation (2007) & $\begin{array}{l}\text { Physics } \\
\text { psychology of } \\
\text { tricks }\end{array}$ & Jim Ottaviani \\
\hline Wire Mothers: Harry Harlow and the Science of Love (2007) & Science of love & Jim Ottaviani \\
\hline Charles R. Knight: Autobiography of an Artist (2005) & $\begin{array}{l}\text { Story of an artist } \\
\text { whose paintings } \\
\text { influenced scientific } \\
\text { fact and fiction of the } \\
20^{\text {th }} \text { century }\end{array}$ & Jim Ottaviani \\
\hline Bone Sharps, Cowboys, and Thunder Lizards (2005) & $\begin{array}{l}\text { Story of the scientists } \\
\text { who discovered } \\
\text { dinosaur fossils }\end{array}$ & Zander Cannon \\
\hline The Stuff of Life (2009) & DNA & Zander Cannon \\
\hline T-minus: the Race to Moon (2009) & $\begin{array}{l}\text { Astronomy: space } \\
\text { journey to the Moon }\end{array}$ & Zander Cannon \\
\hline
\end{tabular}

Table 1. List of science graphic novels. 


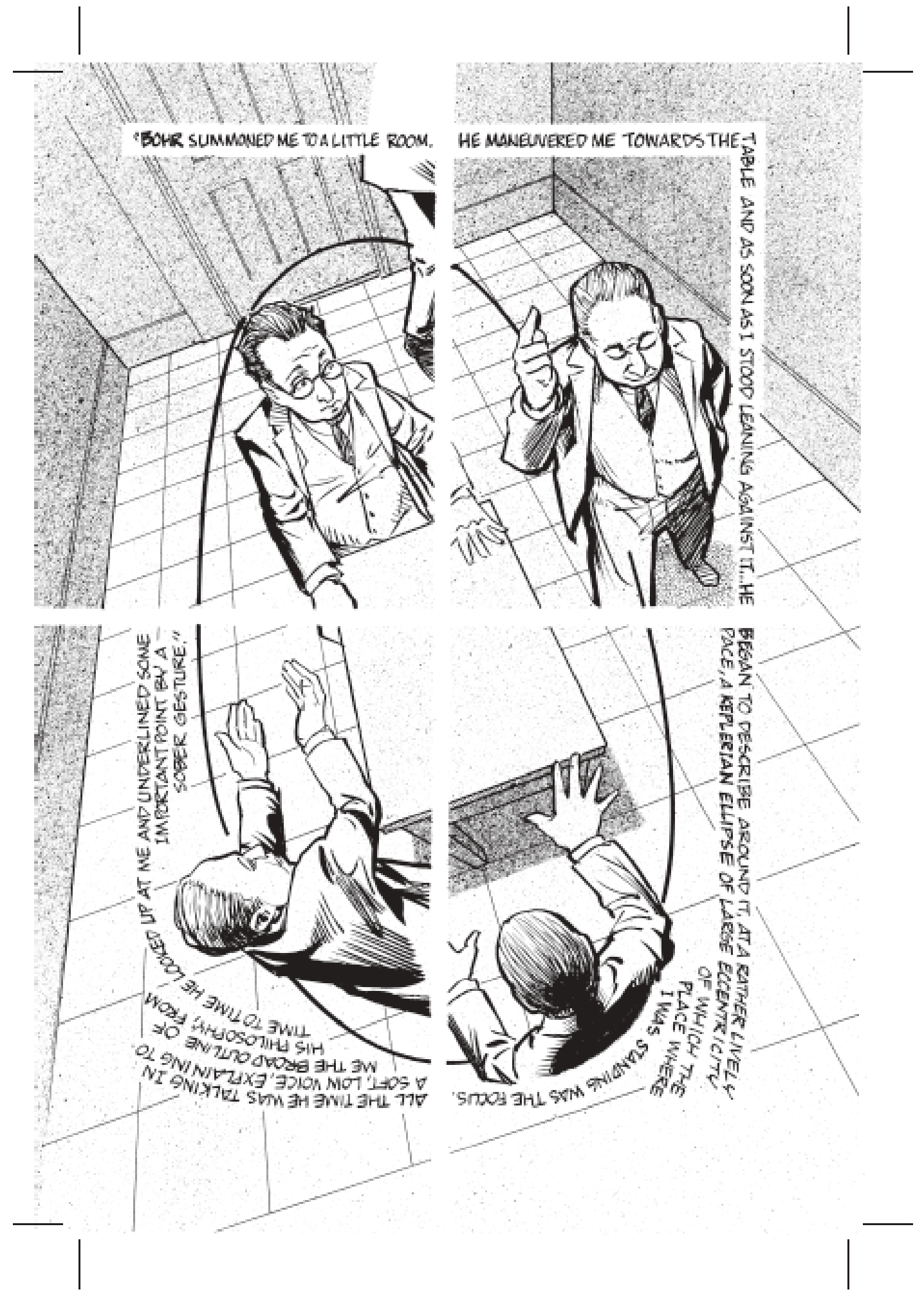

Image 6. An excerpt from Jim Ottaviani’s Suspended in Language graphic novel. Reprinted with permission. 


\section{Role of comics in science communication and the constraint of the medium}

Most comics mentioned here could have a role in one-way science communication under the "dominant view" model of science communication [43]. They use the comic book medium to explain science to the public - an audience that is assumed to lack such knowledge. A more recent model of science communication aims to involve the public in a two-way dialogue with science. This model, Public Engagement with Science and Technology, might also offer opportunities for using science comics. For example, the Battle for Planet Science [44] is a comic that features characters designed by school children as part of a competition for the best super-hero character design and best superpower design, based on scientific principles encountered in class. As the children's input makes a visible difference to the final product, such a comic arguably engages children more actively with science than the other types of science comics discussed. Planet Science comics are therefore more likely to establish a successful "contract" with the readers as suggested by Barker (1989; pp. 256-257): they offer "a kind of relationship to [their] readers" which is similar in its conception to Barker's example of Scream Inn comics, in which readers suggested characters which would appear in each new episode of the comic [45].

Another example of comics that involve the readers more directly than the traditional comic books is the EU's Eco Agents Special Unit series. Although many of the other science comics discussed are available online, the Eco Agents Special Unit series innovatively uses the web platform to its full advantage. Readers have to register in order to access the comics, and as part of registration process they design an avatar which then features in the comic as one of the characters. This presumably enhances identification with the character and helps immerse the reader into the story. As the reader flips through the comic (which has the feel of a book, as the turning of pages is graphically simulated), there are many clickable frames that either provide extra information related to the story, or open up new frames which feature a film, a game or other interactive content (e.g. a quiz).

These comics' plots revolve around secret agents' missions to prevent various ecological incidents. Reading the comic and engaging with its interactive content, the reader collects points with which they then compete for the rank of 'top agent' on the main website, hopefully learning a lot about eco-science along the way. There are also eco-tips featured on the main web site (to which readers can contribute): this makes clear the site's intention that readers should not only engage actively in stories with real-life relevance on the web site, but that they should extend this active ecological engagement into their everyday life (thus thinking of themselves as secret agents with a mission in real life as well as through their avatars). The avatars are also quite 'cool': fashionably dressed and appealing in their design and colour, encouraging readers' to identify with them.

The Battle for Planet Science and Eco Agents Special Unit series are good first steps towards a more advanced way of popularizing science via online comics, using the medium to engage in a two-way dialogue with the audience.

Although comics can be used for communicating science to the public, there may be opportunities for using comics for communication between scientists as well (they are already occasionally published in scientific journals for entertainment, e.g. Adventures in Synthetic Biology in Nature and Interferon Force: Cytokine Storm in Nature Immunology). Comics have been used for various instruction manuals. A recent example is Scott McCloud's comic book manual for the Google Chrome web browser. Will Eisner (1985; p. 139-147) says that the performance of technical tasks that such comics address is sequential in nature, just as comics are, and the success of comics as teaching tools "lies in the fact that the reader can easily relate to the experience demonstrated" [4]. A recently started video journal, JOVE (Journal of Visualized Experiments) states that:

\footnotetext{
Visualization greatly facilitates the understanding and efficient reproduction of both basic and complex experimental techniques, thereby addressing two of the biggest challenges faced by today's life science research community: i) low transparency and poor reproducibility of biological experiments and ii) the time and labor-intensive nature of learning new experimental techniques [46].
}

It would be interesting to see if instructional comics could do just as good a job in describing visually the experimental procedures in sciences as the video can. Could we ever have a Comic Book Journal of Visualized Experiments? Comics would be at an advantage to videos in that a reader can instantly see steps prior and after the one he/she is currently looking at. 
Similarly, some have even suggested replacing textbooks with comics (e.g. see [47]). But if the text in comics is overly didactic it may easily lose connection with the story that is being told resulting in a less interesting read. Another concern in using comics instead of textbooks is that no-one has yet looked at whether comics are still preferred medium by children once its novelty factor has been worn out. Future studies could address this, examining children's response to using comics as textbooks.

The constraint of the comics medium may affect science communication. For example, Eisner (1996) pointed out that artists and writers have to work well together in order to successfully convey a story through the medium of comics [5]. "The ideal writing process occurs where the writer and artist are the same person" he says, and yet most of the science comics I have mentioned so far have different artists and writers [5]. Eisner (1996) maintains that in the process of translation of the script to images, artists can distort the writer's vision and add their own elements to it [5].

So, when discussing science comics one should pay attention to both the visuals and the text. Some have criticized the role of animated visuals in documentary films such as BBC's Walking with Dinosaurs saying that hyper-realistic animations put form over content [48]. Similar problems might happen in science comics as well: if science is made to be fun by use of striking artwork in comics, the artwork might misrepresent the actual science. On the other hand if the aim of the comic is to convey scientific ideas, there might not always be a great plot to go along with the educational material and this may then be hidden by use of impressive artwork. Eisner says that "when high-tech layout and visual pyrotechnics dominate a comic, the result is often a very simple plot" but similarly when a simple plot is all there is "action and special effect art must sustain interest" of the reader [5]. It would be interesting to look at existing science comics and see if there is any relationship with interest of the plot and the standard of the artwork, and indeed if this makes difference to readers of such comics.

Most of these science comics seem to be produced by scientists or at least with help from science advisors. Science advisors, presumably there to ensure accuracy of the scientific content, could easily introduce their own views of science into these comics and may act much like a censorship apparatus. Can there ever be a relationship between these comics and non-scientific readers, a "contract" with readers as Barker (1989) calls it, in which comics cater for some social need of the readers, or will the readers in fact resent institutional messages embedded in such communication attempts [45]? Can such comics ever have any readership outside the classroom?

Instead of uncritically accepting science comics as yet another excellent way to inspire children to study science, perhaps future studies should focus on examining images of science and scientists that these comics contain. If fiction comics contain a large amount of misleading science, do science comics present an objective view of science? If scientists in popular media are usually stereotyped can they ever be presented realistically in a medium that needs and thrives on stereotypes? Eisner (1996; p. 12) says:

\footnotetext{
...the stereotype is a fact of life in the comics medium... In comics, stereotypes are drawn from commonly accepted physical characteristics associated with an occupation. These become icons and are used as part of the language in graphic storytelling. [5]
}

This quotation is followed by stereotypical images among which is the scientist: a short, white male, with glasses, messy hair and moustache holding a book and looking much like the familiar iconic images of Einstein. Can such a medium, then, ever not stereotype scientists?

\section{Conclusion}

This brief review shows that there is a variety of comics about science. These vary in length, style and presentation. Individually, they have been reviewed elsewhere (e.g. [49,50]), and a few blogs and websites provide partial overviews of a variety of science comics and graphic novels that are currently available (e.g. $[40,51,52])$.

Research into these comics and their audiences has been rather scarce. Existing studies highlight the potential benefits of using such comics in science education, but do not address the use of comics and graphic novels as a means of communicating science to people outside classroom settings.

Most of existing studies embrace the use of comics as an exciting way of communicating science. But what all of them assume is that science is great and worthy of being promoted via comics. None of them actually address critically the content of these comics or science itself. What image of science do these 
comics contain? Who decides what image of science goes into comics? How do these comics represent science and the scientists, and how might this affect the readers beside the reported excitement of children of using comics in science classes? There are many questions about science communication through comics that await future study.

\section{Notes and references}

[1] S. Locke (2005), Fantastically reasonable: ambivalence in the representation of science and technology in super-hero comics, Public Understanding of Science 14(1): 25-46.

[2] S. McCloud (1994), Understanding Comics: the Invisible Art, New York, Harper Collins.

[3] S. McCloud (2000), Reinventing Comics: How Imagination and Technology Are Revolutionizing an Art Form, New York, HarperCollins.

[4] W. Eisner (1985), Comics and Sequential Art, Tamarac, Florida, Poorhouse Press.

[5] W. Eisner (1996), Graphic Storytelling and Visual Narrative, Tamarac, Florida, Poorhouse Press.

[6] R. Sabin (2009), This guy is just to die for, The Observer, $23^{\text {rd }}$ August 2009.

[7] D. Buckingham and M. Scanlon (2003), Education, Entertainment and Learning in the Home, Buckingham, Open University Press.

[8] R. Schmitt (1992), Deconstructive Comics, Journal of Popular Culture 25(4): 153-161.

[9] D. Wolk (2007), Reading Comics: How Graphic Novels Work and What They Mean, Philadelphia, De Capo Press.

[10] R. Varnum \& C.T. Gibbons (eds.) (2001), The Language of Comics: Word and Image, Jackson, University Press of Mississippi.

[11] J.M. Vilchez-Gonzales and F.J.P. Palacios (2006), Image of science in cartoons and its relationship with the image in comics, Physics Education 41(3): 240-249.

[12] H.A. Carter (1988), Chemistry in the Comics, Journal of Chemical Education 65(12): 10291036.

[13] R. Nagata (1999), Learning Biochemistry through manga - helping students learn and remember, making lectures more exciting, Biochemical Education 27(4): 200-203.

[14] P. Di Raddo (2006), Teaching Chemistry Lab Safety through Comics, Journal of Chemical Education 83(4): 571-573.

[15] Z. Szafran, R.M. Pike and M.M. Singh (1994), Microscale Chemistry in the Comics, Journal of Chemical Education 71(6): A151.

[16] M. Weinstein (2006), Captain America, Tuskegee, Belmont, and Righteous Guinea Pigs: Considering Scientific Ethics through Official and Subaltern Perspectives, Science and Education 17: 961-975.

[17] E. Barnes (2006), Captain Chemo and Mr Wiggly: Patient Information for Children with Cancer in the Late Twentieth Century, Social History of Medicine 19(3): 501-519.

[18] A. Wignall (2005), Comic Book Guys, The Guardian, available from: http://www.guardian.co.uk/education/2005/jun/07/highereducation.workinprogress, accessed 09 July 2009.

[19] E. Torneo (2006), Superhero Science, Seed, available from: http://seedmagazine.com/content/article/superhero science, accessed 20 July 2009.

[20] L.H. Gresh and R. Weinberg (2002), The Science of Superheroes, Hoboken, New Jersey, John Wiley and Sons, Inc.

[21] J. Kakalios (2005), The Physics of Superheroes, New York, Gotham Books.

[22] N. Conan (2003), Science of Superheroes. NPR radio, available from: http://www.npr.org/templates/story/story.php?storyId=1303605\&ps=rs, accessed $20^{\text {th }}$ August 2009.

[23] G. Rota (2003), "Comics" as a tool for teaching biotechnology in primary schools, Electronic Journal of Biotechnology 6(2), available from: http://www.ejbiotechnology.info/content/vol6/issue2/issues/2, accessed 9 July 2009.

[24] H.A. Carter (1989), Chemistry in the Comics: Part 2. Classic Chemistry, Journal of Chemical Education 66(2): 118-127.

[25] R. Noakes (2002), Science in mid-Victorian Punch, Endeavour 6(3): 92-96. 
[26] A.J. Wright (2002), See you in the Funny Papers: Anaesthesia in cartoons and comics, International Congress Series 1242: 547-551.

[27] B. Hansen (2004), Medical History for the Masses: How American Comic Books Celebrated Heroes of Medicine in the 1940s, Bulletin of the History of Medicine 78(1): 148-191.

[28] L. Kruger and S.P. Watson (2001), Shoo-This book makes me to think!, Education, entertainment and "life-skills" comics in South Africa, Poetics Today 22(2): 475-513.

[29] T. Russell and S. Murray (1993), Popular publishing for environmental and health education: Evaluation of Action Magazine, Liverpool, Liverpool University Press. Cited in: E. Weitkamp and F. Burnet (2007), The Chemedian brings laughter to the chemistry classroom, International Journal of Science Education 29(15): 1911-1929.

[30] E. Weitkamp and F. Burnet (2007), The Chemedian brings laughter to the chemistry classroom, International Journal of Science Education 29(15): 1911-1929.

[31] J.C. Olson (2008), The comic strip as a medium for promoting science literacy, available from: http://www.csun.edu/ jco69120/coursework/697/projects/OlsonActionResearchFinal.pdf, accessed 20 July 2009.

[32] S. Naylor and B. Keogh (1999), Science on the underground: an initial evaluation, Public Understanding of Science 8:105-122.

[33] S. Hughes (2005), Comic Book Science in the Classroom, NPR radio, available from: http://www.npr.org/templates/story/story.php?storyId=4581832, accessed $20^{\text {th }}$ August 2009.

[34] Scientoon website, available from: http://www.scientoon.com/index.htm, accessed $22^{\text {nd }}$ August 2009.

[35] B. Keogh et al. (1998), Concept cartoons: a new perspective on physics education, Physics Education 33(4): 219-224.

[36] Association Sciences sans Frontiers website, available from: http://www.savoir-sans-frontieres.com/JPP/telechargeables/free_downloads.htm - francais, accessed $27^{\text {th }}$ August 2009.

[37] Engineering and Physical Sciences Research Council website, available from: http://gow.epsrc.ac.uk/ViewGrant.aspx?GrantRef=EP/F024282/1, accessed $27^{\text {th }}$ August 2009.

[38] D. Endy and I. Deese (2005), Adventures in Synthetic Biology.

[39] Urquhart and Hairston (2005), CINDI in the Space.

[40] University of Dallas website, available from: http://cindispace.utdallas.edu/education/science_comics.html, accessed $5^{\text {th }}$ June 2009.

[41] D. Macan (2007), I ja želim biti kao Prēlog! Zagreb: Školska Knjiga, available from http://prelog.fkit.hr/program/popularizacija/Prelog strip.pdf, accessed $17^{\text {th }}$ June 2009.

[42] S. Biro (2009), Al otro lado del telescopio: los descubrimientos de Galileo, Mexico City: Ediciones SM.

[43] S. Hilgartner (1990), The Dominant View of Popularization: Conceptual Problems, Political Uses, Social Studies of Science 20: 519-539.

[44] E. Ekevall (2009), Battle for Planet Science, available from: $\mathrm{http} / /$ www.planet-science.com/randomise/index.html?page=/psp/home.html\&page=/psp/battleforplanetscience.html, accessed $2^{\text {nd }}$ August 2009.

[45] M. Barker (1989), Comics, Ideology, Power and the Critics, Manchester, Manchester University Press.

[46] Journal of Visualized Experiments website, available from: http://www.jove.com/index/About.stp, accessed 20 July 2009.

[47] N. Ulaby (2005), Holy Evolution, Darwin! Comics Take On Science, NPR radio, available from http://www.npr.org/templates/story/story.php?storyId=4495248, accessed $21^{\text {st }}$ May 2009.

[48] J. van Dijck (2006), Picturizing Science: The science documentary as multimedia spectacle, International Journal of Cultural Studies 9(1): 5-24.

[49] E. Zielinska (2007), Pass the comics - No, the science ones, The Scientist, available from: http://www.the-scientist.com/templates/trackable/display/news.jsp?type=news\&o_url=news/display/53479\&id=53479, accessed 15 March 2009.

[50] Sarah Hughes (2005), Comic Book Science in the Classroom, NPR radio, available at: http://www.npr.org/templates/story/story.php?storyId=4581832. 
[51] P. Schiendelman (2008), Learning graphically - comics about science, Weblog, available from: http://blog.makezine.com/archive/2008/09/learning_graphically.html accessed $21^{\text {st }}$ May 2009.

[52] J. Meier (2007), An Exciting Experiment Collecting Graphic Novels in the Sciences, available from: http://www.personal.psu.edu/jjm38/sciencegraphicnovels.pdf, accessed $11^{\text {th }}$ August 2008.

\section{Available Online Resources and Links to the Science Comics Mentioned in the Article}

\section{Available Freely:}

Cartoons and short comics trips :

- Newton and Copernicus short comic strips: http://www.newtonandcopernicus.com/ with an in depth description of how to use these: http://www.csun.edu/ jco69120/coursework/697/projects/OlsonActionResearchFinal.pdf

- Scientoons: http://www.scientoon.com/index.htm

Comic books:

- Adventures in Synthetic Biology (English and Spanish versions): http://openwetware.org/wiki/Adventures

- Cindi in Space (available in English and Spanish): http://cindispace.utdallas.edu/education/cindi_comic.html

- EU's Eco Agents interactive online comics (ecology, sustainable energies): http://ecoagents.eea.europa.eu/

- Manga science comic series about atmosphere and the environment (available in English, Japanese and for translation in other languages):

http://www.stelab.nagoya-u.ac.jp/ste-www1/doce/outreach.html\#anc_booklets

- Ozzy Ozone comics (environment, climate, atmosphere): http://www.ozzyozone.org/ozzy_en/ozzycontenu.html

- Planet Science's superhero science and the Battle for the Planet Science comic (conatins a teaching pack for science teachers):

http://www.planet-science.com/randomise/index.html?page=/psp/home.html\&page=/psp/index.html

- Selenia comics (chemistry): http://www.sciencecomics.uwe.ac.uk/

- The Adventures of Archibald Higgins science comics (available in many languages) http://www.savoir-sans-frontieres.com/JPP/telechargeables/free_downloads.htm\#francais

- The Interferon Force comic book series about Immune system (flu virus, multiple sclerosis): http://www.interferonforce.com/

- Vladimir Prelog chemistry comic (in Croatian): http://prelog.fkit.hr/program/popularizacija/Prelog_strip.pdf

- Water Heroes: http://www.on.ec.gc.ca/greatlakeskids/water-heroes-e.html

\section{For pay (many of these contain some free content online):}

- Zander Cannon's comics and graphic novels: http://www.bigtimeattic.com/

- Concept cartoons: http://www.conceptcartoons.com/index_flash.html

- Jay Hossler's comics and graphic novels: http://www.jayhosler.com/

- Jim Ottaviani's comics and graphic novels: http://www.gt-labs.com/

- Max Axiom comic book series:

http:/www.capstonepress.com/aspx/pDetail.aspx?EntityGUID=8bd6f56b-a478-44aa-ba47-93b69dce0b27

- Medikidz comic book series: www.medikidz.com

- The Young Scientist comic: http://www.theyoungscientists.in/products.html 


\section{Author}

Mico Tatalovic. Born in Rijeka, Croatia. BA in Biology at the University of Oxford (2006). MPhi in Zoology at the University of Cambridge (2008). Currently an MSc student in Science Communication at the Imperial College, London. E-mail: mico.tatalovic08@imperial.ac.uk.

How TO CITE: M. Tatalovic, Science comics as tools for science education and communication: a brief, exploratory study, Jcom 08(04) (2009) A02. 